University, in chemistry ; A. M. Macbeath, Queen's University, Belfast, and Clare College, Cambridge, to Princeton University, in mathematics; G. D. S. MacLellan, Pembroke College, Cambridge, to the Massachusetts Institute of Technology, in mechanical engineering ; J. H. Paterson, St. Catharine's College, Cambridge, to the University of Wisconsin, in geography; S. V. Perry, University of Liverpool and Trinity College, Cambridge, to the School of Medicine, University of Rochester, in physiology; R. W. Riddell, University of London, to Duke University, in medicine; Dr. G. A. Smart, University of Durham and University of Bristol, in medicine; I. G. Stewart, University of St. Andrews, to the University of Chicago, in economics; Dr. Alwyn Williams, University College of Wales, Aberystwyth, and University of Cambridge, to the National Museum, Washington, D.C., in geology.

The following have been appointed to Commonwealth Fund Fellowships tenable by candidates from the Home Civil Service: Philip Allen, Queens' College, Cambridge, of the Home Office; R. E. L. Cleaver, New College, Oxford, of the Ministry of Fuel and Power; T. D. Haddow, University of Edinburgh and Trinity College, Cambridge, of the Department of Health for Scotland.

\section{Cambridge Summer Course in Food Science}

A summer course in food science will be held in the University of Cambridge, in co-operation with the Department of Scientific and Industrial Research, at the Low Temperature Research Station during August 30-September 11. The whole field of food science will be surveyed, with the view of suggesting the emphasis which should be placed on various aspects in the basic training of scientific workers for the food industries. A substantial knowledge of chemistry, and some knowledge of biology will be assumed. A detailed syllabus and form of application for admission may be obtained from G. F. Hickson, secretary of the Board of Extra-Mural Studies, Stuart House, Cambridge, to whom the completed application form should be returned not later than July 10.

\section{International Holiday Centre}

ThE French Association of Scientific Workers is organising an International Holiday Centre at Morzine (Haute-Savoie) during July 15-September 1. Morzine, without being a fashionable holiday resort, is one of the beauty spots of the French Alps. It lies to the south of Thonon at a height of about 1,000 metres; and around it are ranges rising to about 2,500 metres. So far as hotels are concerned, the French Association of Scientific Workers can secure accommodation at 800 and 700 francs a day (including service and taxes). It has also secured some good camping sites, and is trying to make arrangements for a canteen. Bookings can only be made for whole weeks (from Monday morning to Sunday night) and for a minimum of two weeks ; registration fee, 500 francs each person. Applications should be made as soon as possible to the Association des Travailleurs Scientifiques, Maison de l'Université Francaise, 47 Boulevard St. Michel, Paris 5.

\section{Modern Applications of Liquid Fuels}

A JorNT conference, arranged by the Institute of Petroleum and the Institute of Fuel, will be held in the University of Birmingham during September 21-23 to discuss "Modern Applications of Liquid
Fuels". The president of the Conference, Mr. J. A. Oriel, will give an address on "The Place of Liquid Fuel in the British Economy" ; subsequent sessions will be devoted to the discussion of papers circulated in advance on fuel oil in the steel industry, other metal industries, glass and ceramic industries; domestic heating; gas turbines for land and marine power purposes; agricultural drying processes; diesel engines; and oil for gas making. Further particulars can be obtained from the general secretary, R. W. Reynolds Davies, 18 Devonshire Street, London, W.1.

\section{Announcements}

THE Minister of Fuel and Power has appointed Dr. H. Roxbee Cox, at present director of the National Gas Turbine Establishment, to be chief scientist at the Ministry of Fuel and Power. Sir Alfred Egerton, professor of chemical technology at the Imperial College of Science and Technology, London, has accepted the invitation of the Minister to be chairman of the Scientific Advisory Council which will be set up to advise him on the scientific aspects of his statutory duties.

Sir Norman Haworth, Mason professor of chemistry and director of the Department of Chemistry in the University of Birmingham, retires at the end of the present session under the age limit. $\mathrm{He}$ is to be succeeded by Prof. H. W. Melville, professor of chemistry in the University of Aberdeen. Dr. K. Mather, head of the Genetics Department of the John Innes Horticultural Institution, Merton, has been appointed to the newly established chair of genetics at Birmingham.

Mr. J. E. Cummins, formerly officer-in-charge of the Information Service of the Council for Scientific and Industrial Research, has been appointed chief scientific liaison officer for Australia in London. $\mathrm{He}$ expects to remain in the United Kingdom for about five years, and will direct the future work of the Australian Scientific Research Liaison Office.

Awards from the Daniel-Pidgeon Fund have been made by the Council of the Geological Society of London to Dr. J. S. Webb, who proposes to investigate the tin-tungsten mineralization in the Hercynian geosyncline as exposed in western Europe, and to Mr. W. S. MeKerrow, who proposes to undertake a statistical investigation of the variation of the brachiopods from fullers' earth.

THE Council of the University of Sheffield has made the following appointments: J. C. Gilbert, senior lecturer in economics; A. Gilbert, lecturer in psychology ; J. H. Davies and S. J. Langley, assistant lecturers in economics ; Brian E. Heard, assistant lecturer in pathology; Peter Freeman, research assistant to the professor of engineering.

THE second annual exhibition organised by the Birmingham Branch of the Society of Inventors will be held in the Chamber of Commerce Building, Birmingham, during October 25-30. The object of the exhibition is to show manufacturers and members of the public new devices that have been produced during the year. Entries for the exhibition are accepted both from members of the Society and from non-members. Anyone wishing to enter an exhibit, which must be either patented, protected or of registered design, should write to the secretary, Mr. B. Thornton Clark, 244 Stoney Lane, Yardley, Birmingham 25. 